\title{
Length-weight relationship and condition factor for 7 loliginid squid species in Mexican waters
}

\section{Relación longitud-peso y factor de condición para 7 especies de calamares loligínidos de aguas mexicanas}

\author{
Jasmín Granados-Amores ${ }^{1}$, César Augusto Salinas-Zavala ${ }^{2}$, Juan Ramón Flores-Ortega ${ }^{1}$, \\ Mariana Díaz-Santana-Iturrios ${ }^{3 *}$ \\ 1 Escuela Nacional de Ingeniería Pesquera, Apartado Postal 10, San Blas, Nayarit, Mexico. \\ 2 Centro de Investigaciones Biológicas del Noroeste, Avenida Instituto Politécnico Nacional, no. 195, colonia \\ Playa Palo de Santa Rita, CP 23096, La Paz, Baja California Sur, Mexico. \\ 3 Universidad Autónoma de Nayarit, Carretera Tepic-Compostela, km 9, C.P. 63155, Xalisco, Nayarit, Mexico.
}

* Corresponding author. E-mail: marianadiazsani@gmail.com

\begin{abstract}
The length-weight relationship and the condition factor are key parameters in stock assessment. Despite the fisheries potential loliginid squids have in Mexico, the group is scarcely known and no formal management has been implemented. A total of 1,105 squids captured on the Pacific and Atlantic coasts of Mexico were measured to estimate length-weight relations and condition factors. Except for Lolliguncula brevis and Lolliguncula argus, all species showed negative allometric growth. The 2 species with isometric growth showed a poor condition, according to Fulton's condition factor, and the rest of the species were in good health, according to the relative condition factor. The type of growth exhibited by the species identified in this study could be associated with their swimming habits or otherwise be affected by the same variables that determine the type of growth of other squid found in Mexican waters. The parameters evaluated in this research are now available for incorporation in further fishery stock assessment models for loliginid squids.
\end{abstract}

Keywords: parameter, Loliginidae, teuthid, coefficient, measurement.

RESUMEN. La relación longitud-peso y el factor de condición son parámetros primarios en la evaluación de poblaciones pesqueras. A pesar del potencial pesquero de los calamares loligínidos en México, el grupo es escasamente conocido y no hay un manejo formal implementado. Un total de 1,105 calamares capturados en aguas mexicanas del Pacífico y del Atlántico fueron medidos para estimar la relación longitud-peso y los factores de condición. Excepto Lolliguncula brevis y Lolliguncula argus, todas las especies presentaron crecimiento alométrico negativo. Las 2 especies con crecimiento isométrico presentaron una condición pobre, según el factor de condición de Fulton, y el resto de las especies presentaron buena condición de salud, según el factor de condición relativo. El tipo de crecimiento encontrado en las especies identificadas en este estudio puede estar relacionado con sus hábitos de nado o, de otra manera, puede ser afectado por las mismas variables que determinan el tipo de crecimiento de otros calamares encontrados en aguas mexicanas. Los parámetros evaluados en esta investigación ahora se encuentran disponibles para ser incorporados en futuros modelos de manejo de poblaciones pesqueras de calamares loligínidos.

Palabras clave: parámetro, Loliginidae, téutido, coeficiente, medida.

\section{INTRODUCTION}

More than half of the species (30) in the family Loliginidae Lesueur, 1821 are commercially important (Roper et al. 1995), though most of them are captured as bycatch in numerous coastal trawl fisheries (Zeidberg et al. 2006, Arkhipkin et al. 2015). In Mexico, loliginid squids are incidentally captured in shrimp and demersal-fish fisheries, with no management regulation. Because this squid group is scarcely known in Mexico, all squids caught as bycatch are generalized as "unidentified squid" in national fishery statistics (Alejo-Plata et al. 2001, Judkins et al. 2009, CONAPESCA 2018).

The length-weight relationship (LWR) is one of the most important fishery parameters in statistical modeling,

\section{INTRODUCCIÓN}

Más de la mitad de las especies (30) de la familia Loliginidae Lesueur, 1821 son comercialmente importantes (Roper et al. 1995), aunque la mayoría de ellas son capturadas incidentalmente por numerosas pesquerías de arrastre costeras (Zeidberg et al. 2006, Arkhipkin et al. 2015). En México, los calamares loligínidos son capturados de manera incidental por las pesquerías de camarón y peces demersales, sin regulación de manejo alguna. Este grupo de calamares es poco conocido en México y, por lo tanto, todas las especies de calamar capturadas incidentalmente se generalizan como "calamar sin especificar" en las estadísticas pesqueras nacionales (Alejo-Plata et al. 2001, Judkins et al. 2009, CONAPESCA 2018). 
for example in executing catch-at-age or catch-at-size models and the stock synthesis model (Quinn and Deriso 1999, Zepeda-Benitez et al. 2017), since LWR is a useful tool in analyzing key biological aspects, for example in estimating biomass from length observations and converting biomass to number of individuals, which is advisable for stock assessment of fast-growing species such as squid (Le Cren 1951, Alford and Jackson 1993, Froese 2006). Another significant biological parameter is the condition factor, which reveals the physiological status of individuals and can be related to growth rate, phenotypic variability, or the health status of aquatic ecosystems inhabited by the species under study (Blackwell et al. 2000). In this study, we aimed to estimate the LWR and condition factor for loliginid squids captured in Mexican waters.

\section{MATERIALS AND METHODS}

Loliginid squids $(N=1,105)$ captured on the Pacific and Atlantic coasts of Mexico were evaluated in our study. Squids were sampled along the coast from the state of Baja California to the state of Oaxaca, including the Gulf of California $\left(32^{\circ} 37^{\prime} 75^{\prime \prime}-16^{\circ} 24^{\prime} 36^{\prime \prime} \mathrm{N} ; 117^{\circ} 01^{\prime} 95^{\prime \prime}-\right.$ $92^{\circ} 24^{\prime} 31^{\prime \prime} \mathrm{W}$ ), and along the coast of the state of Tamaulipas, in the Gulf of Mexico $\left(22^{\circ} 12^{\prime} 31^{\prime \prime}-27^{\circ} 40^{\prime} 42^{\prime \prime} \mathrm{N} ; 7^{\circ} 08^{\prime} 38^{\prime \prime}-\right.$ $\left.100^{\circ} 08^{\prime} 51^{\prime \prime} \mathrm{W}\right)$. Squids were captured with typical fishing nets used for catching demersal fish and shrimp, and specimens were obtained from landing areas and local markets and during oceanographic cruises conducted in the period from 2011 to 2014. Species were identified using specialized identification guides (e.g., Jereb et al. 2010). The dorsal mantle length (DML) and total weight of each squid were recorded.

To assess the relationship between weight increase and DML, the following potential equation was employed: $W=a \times \mathrm{DML}^{b}$, where $W$ is squid weight, $a$ is the coefficient of proportionality, and $b$ is the allometry coefficient. To estimate the type of growth, Student's $t$ test was performed using the $b$ values that were obtained from the model and compared with the theoretical value of $b=3$, which represents isometric growth. Fulton's condition factor $(\mathrm{K})$ was estimated for species having isometric growth using the following formula: $K=100 \times\left(W / \mathrm{DML}^{3}\right)$. The relative condition factor $(K n)$ was calculated for species having allometric growth using the following formula: $K n=W / a \times \mathrm{DML}^{b}$.

\section{RESULTS}

The following species were identified: Doryteuthis pealeii $(N=50, \mathrm{DML}=67.7-213.0 \mathrm{~mm})$, Doryteuthis plei $(N=50, \mathrm{DML}=33.0-638.0 \mathrm{~mm})$, and Lolliguncula brevis $(N=11, \mathrm{DML}=40.0-71.0 \mathrm{~mm})$ on the Atlantic coast, and Lolliguncula diomedeae $(N=263, \mathrm{DML}=44.7-98.4 \mathrm{~mm})$, Lolliguncula panamensis $(N=467, \mathrm{DML}=20.1-112.0 \mathrm{~mm})$,
La relación longitud-peso (RLP) es uno de los parámetros pesqueros más importantes en la modelación estadística, como, por ejemplo, en la ejecución de modelos de captura por edad o captura por talla y el modelo de síntesis de una población pesquera (Quinn y Deriso 1999, Zepeda-Benitez et al. 2017), ya que la RLP es una herramienta útil en el análisis de aspectos biológicos clave como, por ejemplo, en la estimación de la biomasa a partir de observaciones de longitud y la conversión de la biomasa a número de individuos, lo cual se recomienda para el manejo de poblaciones pesqueras de especies con crecimiento rápido como el calamar (Le Cren 1951, Alford y Jackson 1993, Froese 2006). Otro parámetro biológico significativo es el factor de condición, el cual indica el estado físiológico de los individuos y puede relacionarse con la tasa de crecimiento, la variabilidad fenotípica o la salud de los ecosistemas acuáticos habitados por las especies estudiadas (Blackwell et al. 2000). En el presente estudio nuestro objetivo fue estimar la RLP y el factor de condición de calamares loligínidos capturados en aguas mexicanas.

\section{MATERIALES Y MÉTODOS}

En este estudio evaluamos calamares loligínidos $(N=$ 1,105) capturados en las costas mexicanas del Pacífico y del Atlántico. Los calamares fueron muestreados a lo largo de la costa desde Baja California hasta Oaxaca, incluido el golfo de California (32 $\left.37^{\prime} 75^{\prime \prime}-16^{\circ} 24^{\prime} 36^{\prime \prime} \mathrm{N} ; 117^{\circ} 01^{\prime} 95^{\prime \prime}-92^{\circ} 24^{\prime} 31^{\prime \prime} \mathrm{W}\right)$, y a lo largo de la costa de Tamaulipas, en el golfo de México $\left(22^{\circ} 12^{\prime} 31^{\prime \prime}-27^{\circ} 40^{\prime} 42^{\prime \prime} \mathrm{N} ; 97^{\circ} 08^{\prime} 38^{\prime \prime}-100^{\circ} 08^{\prime} 51^{\prime \prime} \mathrm{W}\right)$. Los calamares fueron capturados con redes pesqueras típicas para la captura de peces demersales y camarón, y los especímenes fueron obtenidos en áreas de arribo pesquero, mercados locales y cruceros oceanográficos que se llevaron a cabo en el periodo de 2011 a 2014. Se usaron guías de identificación especializadas (e.g., Jereb et al. 2010) para identificar a las especies. Se midieron la longitud del manto dorsal (LMD) y el peso total de cada calamar.

Para evaluar la relación entre el aumento en peso y la LMD, se usó la siguiente ecuación potencial: $P=a \times \mathrm{LMD}^{b}$, donde $P$ es el peso del calamar, $a$ es el coeficiente de proporcionalidad y $b$ es el coeficiente de alometría. Para estimar el tipo de crecimiento, se le aplicó la prueba $t$ de Student a los valores $b$ que se obtuvieron del modelo y se compararon con el valor teórico de $b=3$, el cual representa crecimiento isométrico. El factor de condición de Fulton $(K)$ se estimó para las especies que presentaron crecimiento isométrico mediante la fórmula $K=100 \times\left(P / \mathrm{LMD}^{3}\right)$. El factor de condición relativa $(K n)$ se calculó para las especies que presentaron crecimiento alométrico mediante la fórmula $\mathrm{Kn}=P / a \times \mathrm{LMD}^{b}$.

\section{Resultados}

Se identificaron las siguientes especies: Doryteuthis pealeii $(N=50, \mathrm{DML}=67.7-213.0 \mathrm{~mm})$, Doryteuthis plei 
Lolliguncula argus $(N=64, \mathrm{DML}=40.4-45.7 \mathrm{~mm})$, and Doryteuthis opalescens $(N=200, \mathrm{DML}=17.6-55.4 \mathrm{~mm})$ on the Pacific coast. The largest squid was a $D$. pealeii individual (213.00 mm DML), and the smallest a $D$. opalescens individual (17.61 mm DML). For all loliginid squids, except $L$. argus and $L$. brevis, the allometry coefficients obtained with Student's $t$ test were statistically different from the theoretical value of $3(P<0.05)$, indicating negative allometric growth. The low coefficient of determination $(<0.60)$ values estimated with the potential LWR model for $L$. diomedeae, L. argus, and D. opalescens demonstrated that the populations of these species are comprised of different intraspecific groups or stocks (Fig. 1). Kn values were $>1.00$ for all species except $L$. panamensis, though its corresponding value was close to $1.00(0.99)$. The highest value (10.64) was detected for $D$. opalescens, evincing its great size in terms of weight and DML. $K$ values were $<1.00$ for the 2 species analyzed (Fig. 2).

\section{Discussion}

In this study, the LWR and condition factor were determined for Loliginidae individuals captured on the Atlantic (3 species) and Pacific (4 species) coasts of Mexico. Considering the swimming strategies of other aquatic organisms, Helfman et al. (2009) found that, in most fish, the energy cost of locomotion in a water mass decreased as fish size increased. The type of growth detected in most of the squid species examined in our study (negative allometric growth) can be explained by their daily and seasonal swimming habits. Several loliginid species undertake significant daily migrations, congregating in bottom waters (some species at $700 \mathrm{~m}$ depth) during daylight and ascending and dispersing in the water column at night. Moreover, some loliginid species perform seasonal migrations in relation to water temperature (e.g., D. pealeii seasonally travels up to $600 \mathrm{~km}$ ) (Roper and Young 1975, Roper et al. 1984). Therefore, the negative allometric growth of these loliginids is favorable in terms of the energy cost of their migration habits. On the other hand, L. argus and L. brevis tended to increase body thickness in proportion to size, and their swimming behavior is accordingly related to the type of growth we detected (isometric growth). Given that both are coastal, shallow-water dwellers (e.g., L. brevis is a slow swimmer, regularly restricted to very shallow waters) (Roper and Young 1975, Brakoniecki and Roper 1985, Bartol et al. 2001), the swimming energy requirements for these 2 species are not as demanding as for the rest of the taxa analyzed; however, it is worth noting that the observations made for $L$. brevis in this study are not conclusive because of the low number of examined individuals. Another explanation for the types of growth exhibited by teuthids was posed by Bazzino-Ferreri (2014), who analyzed length-weight data for the Humboldt squid, Dosidicus gigas, over a
$(N=50, \mathrm{DML}=33.0-638.0 \mathrm{~mm})$ y Lolliguncula brevis $(N=11, \mathrm{DML}=40.0-71.0 \mathrm{~mm})$ en la costa del Atlántico, y Lolliguncula diomedeae $(N=263$, DML $=44.7-98.4 \mathrm{~mm})$, Lolliguncula panamensis $(N=467, \mathrm{DML}=20.1-112.0 \mathrm{~mm})$, Lolliguncula argus $(N=64, \mathrm{DML}=40.4-45.7 \mathrm{~mm})$ y Doryteuthis opalescens $(N=200, \mathrm{DML}=17.6-55.4 \mathrm{~mm})$ en la costa del Pacífico. El calamar más grande fue un individuo de $D$. pealeii (213.00 mm LMD), y el más pequeño un individuo de $D$. opalescens (17.61 mm LMD). Para todas las especies de calamares loligínidos, excepto $L$. argus y L. brevis, los coeficientes de alometría que se obtuvieron con la prueba $t$ de Student presentaron diferencias estadísticas con respecto al valor teórico de $3(P<0.05)$, lo que indica crecimiento alométrico negativo. El bajo coeficiente de determinación $(<0.60)$ estimado de acuerdo con el modelo potencial de RLP para L. diomedeae, L. argus y D. opalescens evidenció que las poblaciones de estas especies están conformadas por distintos grupos intraespecíficos o poblaciones pesqueras (Fig. 1). Los valores de Kn fueron $>1.00$ para todas las especies excepto para L. panamensis, aunque el valor correspondiente a esta especie fue cercano a 1.00 (0.99). El valor más alto (10.64) se detectó en D. opalescens, lo cual evidenció su gran tamaño con respecto al peso y la LMD. Los valores de $K$ fueron $<1.00$ para las 2 especies analizadas (Fig. 2).

\section{Discusión}

En este estudio, la RLP y el factor de condición se determinaron para individuos de la familia Loliginidae capturados en la costas mexicanas del Atlántico ( 3 especies) y del Pacífico (4 especies). Al considerar las estrategias de nado de otros organismos acuáticos, Helfman et al. (2009) observaron que, para la mayoría de los peces, el costo energético de la locomoción en una masa de agua disminuye conforme aumenta el tamaño del pez. El tipo de crecimiento detectado en la mayoría de las especies de calamar examinadas en nuestro estudio (crecimiento alométrico negativo) se puede explicar por sus hábitos de nado diarios y estacionales. Varias especies de loligínidos realizan migraciones verticales diariamente; permanecen en grupos en el fondo durante el día (algunas especies superando $700 \mathrm{~m}$ de profundidad) y ascienden hasta cierto punto y se dispersan en la columna de agua durante la noche. Asimismo, algunas especies de loligínidos realizan migraciones estacionales relacionadas con la temperatura del agua (e.g., D. pealeii migra hasta $600 \mathrm{~km}$ estacionalmente) (Roper y Young 1975, Roper et al. 1984). Por lo tanto, el crecimiento alométrico negativo de estos loligínidos es favorable en términos del costo energético de sus hábitos migratorios. Por otro lado, L. argus y L. brevis presentaron una tendencia hacia el aumento del grosor corporal proporcional al tamaño, y sus comportamientos natatorios se relacionaron, por consiguiente, con el tipo de crecimiento detectado (crecimiento isométrico). Debido a que ambas especies son costeras y de 

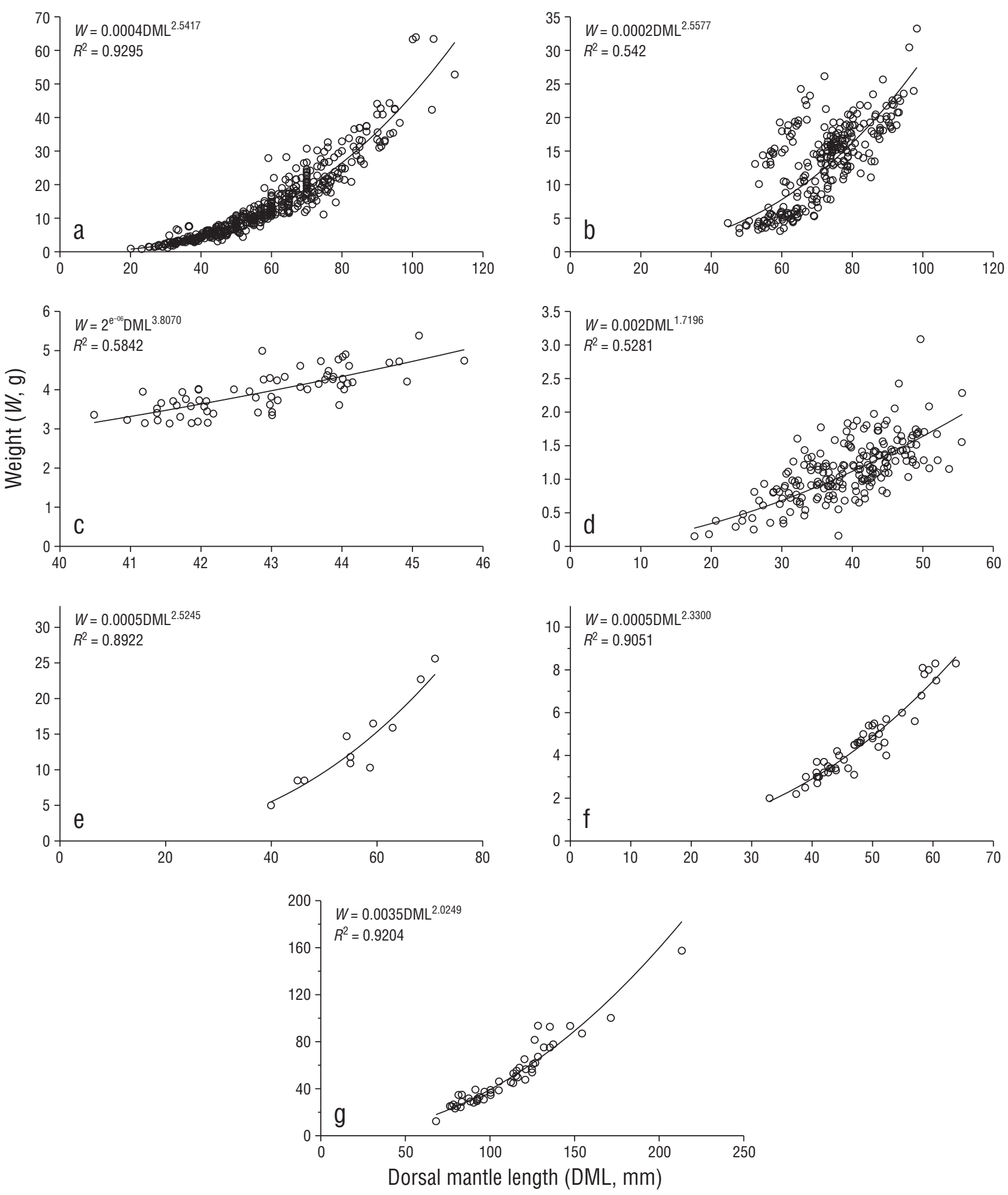

Figure 1. Length-weight relationship for the loliginid squids evaluated in this study.

Figura 1. Relación longitud-peso para los calamares loligínidos evaluados en este estudio.

(a) Lolliguncula panamensis, (b) Lolliguncula diomedeae, (c) Lolliguncula argus, (d) Doryteuthis opalescens, (e) Lolliguncula brevis, (f) Doryteuthis plei, (g) Doryteuthis pealeii. 

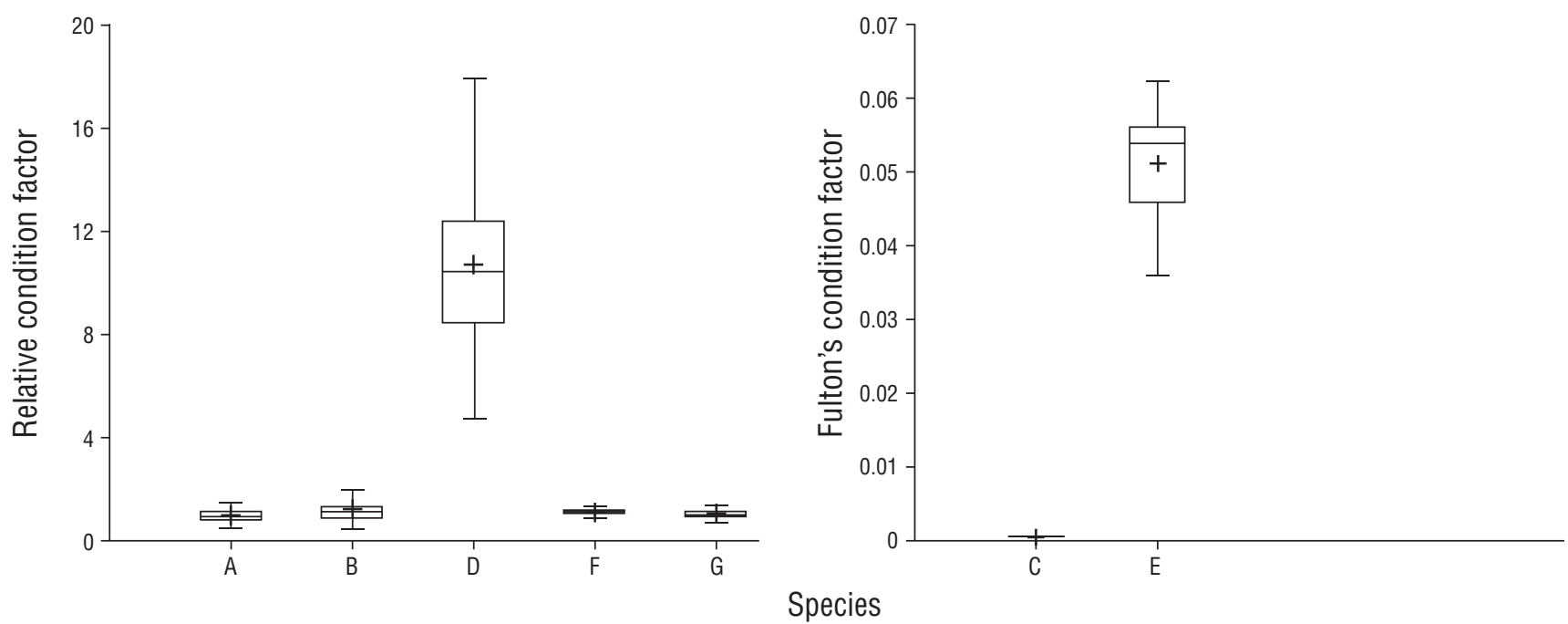

Figure 2. Relative condition factor and Fulton's condition factor for the loliginid squids evaluated in this study.

Figura 2. Factor de condición de Fulton y factor de condición relativa para los calamares loligínidos evaluados en este estudio.

(a) Lolliguncula panamensis, (b) Lolliguncula diomedeae, (c) Lolliguncula argus, (d) Doryteuthis opalescens, (e) Lolliguncula brevis, (f) Doryteuthis plei, (g) Doryteuthis pealeii.

10-year period (1996-2006). This author concluded that the type of growth and the condition factor of this squid vary according to latitude, year or season, population size range, and environmental conditions. Since ours is the only study addressing the LWR and condition factor for loliginid squids in Mexican waters, we have no point of comparison, but it is highly likely that these 2 factors are affected by the same variables affecting $D$. gigas growth and condition. Further systematic studies should be performed to confirm this statement considering that the Humboldt squid and our loliginids belong to different orders.

Regarding the condition of loliginid squids, the species with isometric growth showed a poor condition (low $K$ values), while the rest of the species showed a good relative condition $(K n>1.00)$. The $K$ and $K n$ values we report here can be employed as reference for comparative purposes in further research (e.g., aquaculture). Doryteuthis opalescens showed the best condition $(K n>10)$ among the species analyzed, and this can be related to intense gonad activity, given that maturation and growth of reproductive organs in this species depend directly on the energy obtained from food; in addition, the excellent condition of this species indicates that it is highly likely that squid were collected in spawning areas (Jereb et al. 2010).

In this study, most loliginid species collected in Mexican waters showed negative allometric growth. The type of growth found in each of the taxa could be related to their migration habits in the water column or otherwise be affected by latitude, population size range, environmental variables, and year or season. The LWR and condition factors for these squid species are now available to be incorporated in further fishery stock assessment models. aguas superficiales (e.g., L. brevis es una especie de nado lento, regularmente restringida a aguas muy superficiales) (Roper y Young 1975, Brakoniecki y Roper 1985, Bartol et al. 2001), los requerimientos energéticos del nado de estas 2 especies no son tan altos como los del resto de los taxones analizados; sin embargo, es importante aclarar que las observaciones realizadas para $L$. brevis en este estudio no son concluyentes debido al bajo número de individuos evaluados. Bazzino-Ferreri (2014) analizó 10 años (19962006) de datos de longitud y peso del calamar de Humboldt, Dosidicus gigas, y presentó otra postura con respecto al crecimiento de los téutidos. El autor concluyó que el tipo de crecimiento y el factor de condición de estos calamares varían con la latitud, el año o la estación, el tamaño de la población y las condiciones ambientales. Debido a que el presente trabajo es el único que aborda la RLP y el factor de condición de los calamares loligínidos de aguas mexicanas, es muy probable que estos 2 factores sean afectados por las mismas variables que afectan el crecimiento y la condición de $D$. gigas. Se requieren más estudios sistemáticos para poder corroborar esta declaración, ya que el calamar de Humboldt y los loligínidos pertenecen a ordenes diferentes.

Con respecto a la condición de los calamares loligínidos, las especies con crecimiento isométrico presentaron una condición pobre (valores bajos de $K$ ), mientras que el resto de las especies presentaron buena condición relativa $(K n>1.00)$. Los valores de $K$ y $K n$ que aquí reportamos pueden ser usados como referencia en futuros estudios con propósitos comparativos (e.g., en acuacultura). Doryteuthis opalescens presentó la mejor condición $(K n>10)$ entre las especies analizadas, y esto puede estar relacionado con una intensa actividad gonádica, ya que la madurez y el crecimiento de los órganos reproductivos en esta especie derivan directamente de la energía 


\section{ACKNOWLEDGMENTS}

JGA is thankful for the financial support granted by the Mexican Program for Proffessional Educational Development at the graduate level (Programa para el Desarrollo Profesional Docente, para el Tipo Superior) through the project "Estructura poblacional de los calamares Lolliguncula panamensis y L. diomedeae (Myopsida: Loliginidae) en la costa del Pacifico mexicano".

\section{REFERENCES}

Alejo-Plata MC, Cerdenares G, Herrera JE. 2001. Cefalópodos lologínidos en la fauna de acompañamiento del camarón. Ciencia y Mar 5(13): 43-48.

Alford RA, Jackson GD. 1993. Do cephalopods and larvae of other taxa grow asymptotically? Am. Nat. 141(5): 717-728. https://doi.org/10.1086/285501

Arkhipkin AI, Rodhouse PGK, Pierce GJ, Sauer W, Sakai M, Allcock L, Arguelles J, Bower JR, Castillo G, Ceriola L, et al. 2015. World squid fisheries. Rev. Fish. Sci. Aquac. 23(2): 92-252. http://dx.doi.org/10.1080/23308249.2015.1026226

Bartol IK, Patterson MR, Mann R. 2001. Swimming mechanics and behavior of the shallow-water brief squid Lolliguncula brevis. J. Exp. Biol. 204(Pt 21): 3655-3682.

Bazzino-Ferreri GA. 2014. Length-weight relationships and condition factors of the Humboldt squid (Dosidicus gigas) from the Gulf of California and the Pacific Ocean. J. Shellfish Res. 33(3): 769-780. http://dx.doi.org/10.2983/035.033.0311

Blackwell BG, Brown ML, Willis DW. 2000. Relative weight (Wr) status and current use in fisheries assessment and management. Rev. Fish. Sci. 8(1): 1-44.

https://doi.org/10.1080/10641260091129161

Brakoniecki TF, Roper CFE. 1985. Lolliguncula argus, a new species of loliginid squid (Cephalopoda: Myopsida) from the Tropical Eastern Pacific. Proc. Biol. Soc. Wash. 98(1): 47-53.

[CONAPESCA] Consejo Nacional de Acuacultura y Pesca. 2018. Estadistíca Pesquera y Acuícola de México. Mexico: Gobierno de México; [accessed 2018 February 15]. https://www.gob.mx/ conapesca/documentos/estadistica-pesquera-y-acuicola-demexico

Froese R. 2006. Cube law, condition factor and weight-length relationships: history, meta-analysis and recommendations. J. Appl. Ichthyol. 22(4): 241-253.

http://dx.doi.org/10.1111/j.1439-0426.2006.00805.x

Helfman GS, Collette BB, Facey DE, Bowen BW. 2009. The diversity of fishes. 2nd ed. United Kingdom: Wiley-Blackwell; $720 \mathrm{pp}$.

Jereb P, Vecchione M, Roper CFE. 2010. Family Loliginidae. In: Jereb P, Roper CFE (eds.), Cephalopods of the world: An Annotated and Illustrated Catalogue of Cephalopod Species Known to Date. Vol. 2, Myopsid and Oegopsid Squids. FAO Species Catalogue for Fishery Purposes; no. 4. Rome (Italy): Food And Agriculture Organization of the United Nations; pp. 38-117.

Judkins HL, Vecchione M, Roper CFE. 2009. Cephalopoda (Mollusca) of the Gulf of Mexico. In: Felder DL, Camp DK obtenida del alimento; a su vez, la excelente condición de esta especie indica que es altamente probable que los calamares fueron recolectados en áreas de reproducción (Jereb et al. 2010).

En este estudio, la mayoría de las especies de calamares loligínidos recolectados en aguas mexicanas presentaron un crecimiento alométrico negativo. El tipo de crecimiento encontrado en cada taxón puede estar relacionado con sus hábitos de migración en la columna de agua o, alternativamente, puede ser afectado por la latitud, el tamaño de la población, las variables ambientales y el año o la estación. La RLP y los factores de condición de estas especies de calamar ahora están disponibles para ser incorporados en subsecuentes modelos de manejo de poblaciones pesqueras.

\section{Agradecimientos}

JGA agradece el apoyo financiero otorgado por el Programa para el Desarrollo Profesional Docente, para el Tipo Superior para el proyecto "Estructura poblacional de los calamares Lolliguncula panamensis y L. diomedeae (Myopsida: Loliginidae) en la costa del Pacifico mexicano".

(eds.), Gulf of Mexico, Origin, Waters, and Biota. Vol. 1, Biodiversity. Texas (USA): A\&M University Press; p. 701-709.

Le Cren ED. 1951. The length-weight relationship and seasonal cycle in gonad weight and condition in the perch (Perca fluviatilis). J. Anim. Ecol. 20(2): 201-219. https://doi.org/10.2307/1540

Quinn TR, Deriso RB. 1999. Quantitative Fish Dynamics. UK: Oxford University Press; 560 pp.

Roper CFE, Young RE. 1975. Vertical distribution of pelagic Cephalopods. Smithsonian contributions to zoology; no. 209. Washington, DC: Smithsonian Institution Press; 51 pp. https://doi.org/10.5479/si.00810282.209

Roper CFE, Sweeney MJ, Nauen CE, 1984. FAO Species Catalogue. Vol. 3, Cephalopods of the World: An Annotated and Illustrated Catalogue of Species of Interest to Fisheries. FAO Fisheries Synopsis; no. 125. Rome (Italy): Food and Agriculture Organization of the United Nations.

Roper CFE, Sweeney MJ, Hochberg FG. 1995. Cefalópodos. In: Fisher W, Krupp F, Schneider W, Sommer C, Carperter KE, Niem VH (eds.), Guía FAO para la Identificación de Especies para los Fines de la Pesca, Pacífico Centro-Oriental. Vol. 1, Plantas e invertebrados. Rome (Italy): Food and Agriculture Organization of the United Nations.

Zeidberg LD, Hamner WM, Nezlin NP, Henry A. 2006. The fishery for California market squid (Loligo opalescens) (Cephalopoda: Myopsida), from 1981 through 2003. Fish. Bull. 104(1): 46-59.

Zepeda-Benitez VY, Morales-Bojórquez E, Díaz-Uribe JG, Nevárez-Martínez MO, Hernández-Herrera A, López-Martínez J. 2017. Implementation of catch-at-age model for the jumbo squid Dosidicus gigas. Ecol. Model. 344: 6-16. http://dx.doi.org/10.1016/j.ecolmodel.2016.10.019

Received June 2019, accepted October 2019. 